ISSN 2080-5993

e-ISSN 2449-9811

\title{
Michał Comporek
}

Uniwersytet Łódzki

e-mail: michal.comporek@o2.pl

\section{RELACJE STRUKTURY FINANSOWANIA \\ Z EKONOMICZNĄ EFEKTYWNOŚCIĄ AKTYWÓW OBROTOWYCH PRZEMYSLOWYCH SPÓŁEK GIELDOWYCH}

\section{THE RELATIONSHIP BETWEEN THE FINANCING STRUCTURE AND THE ECONOMIC EFFICIENCY OF CURRENT ASSETS IN INDUSTRIAL LISTED COMPANIES}

DOI: $10.15611 /$ nof.2016.3.03
JEL Classification: G32, L20

Streszczenie: Zasadniczym celem artykułu jest scharakteryzowanie związków zachodzących między wartością i strukturą źródeł finansowania przedsiębiorstwa a efektywnością ekonomiczną gospodarowania aktywami obrotowymi - mierzoną zarówno z perspektywy fundamentalnych podstaw tej efektywności, tkwiących w sprawnych procesach logistyki, produkcji i sprzedaży, jak i z uwzględnieniem cyklu obrotowego przedsiębiorstwa. Dla operacjonalizacji sformułowanego celu badawczego postawione zostały hipotezy badawcze stwierdzające, że: w giełdowych spółkach przemysłowych występują silne, negatywne związki korelacyjne między uzyskiwaną efektywnością ekonomiczną aktywów obrotowych a stopniem sfinansowania majątku całkowitego kapitałem własnym, a zarazem w jednostkach tych notuje się występowanie silnej, pozytywnej relacji między efektywnością aktywów obrotowych a wskaźnikiem wspierania finansowego przedsiębiorstwa. Badania empiryczne zrealizowane zostały wśród spółek publicznych należących do sektora przemysłu, które były notowane na rynku głównym Giełdy Papierów Wartościowych w Warszawie w latach 2006-2014 oraz których akcje były przedmiotem obrotu przez co najmniej pięć lat.

Słowa kluczowe: struktura kapitału, struktura finansowania, aktywa obrotowe, efektywność ekonomiczna.

Summary: The main aim of this article is to characterize the relationship between the value and the structure of company's capital and economic efficiency of owned current assets in these enterprises. The research hypotheses claim that in the industrial listed companies there is a strong, negative correlation between the obtainable level of economic efficiency of current assets and the equity-to-total assets ratio, but on the other hand in these enterprisies there is recorded occurrence of a strong, positive correlation between economic efficiency of current assets and the debt-to-equity ratio. Empirical studies have been carried out among industrial 
companies listed on the Warsaw Stock Exchange in the years 2006-2014, that shares were traded on the stock exchange for a period of minimum five years.

Keywords: capital structure, financing structure, current assets, economic efficiency.

\section{Wstęp}

Kształtowanie ekonomicznej efektywności aktywów obrotowych jest uwarunkowane wieloma różnorodnymi procesami należącymi nie tylko do sfery logistyki, produkcji czy sprzedaży wytworzonych produktów przez przedsiębiorstwo. W systemie determinant efektywności tych aktywów znajdują się także finansowe wyznaczniki funkcjonowania i rozwoju podmiotu gospodarczego. To zespolenie realnych i finansowych procesów gospodarowania znajduje bezpośredni wyraz w efektywności ekonomicznej aktywów obrotowych, którą można oceniać z wielu perspektyw, lecz zawsze z uwzględnieniem ich właściwości, funkcji i miejsca w systemie ekonomiczno-finansowym przedsiębiorstwa.

Zasadniczym celem artykułu jest ocena związków zachodzących między ekonomiczną efektywnością aktywów obrotowych a strukturą kapitałową i finansową giełdowych spółek przemysłowych. Dla operacjonalizacji sformułowanego celu badawczego postawione zostały dwie hipotezy badawcze, stwierdzające, że:

- HP.1. W giełdowych spółkach przemysłowych ma miejsce występowanie silnego, negatywnego związku korelacyjnego między uzyskiwaną efektywnością ekonomiczną aktywów obrotowych a stopniem sfinansowania majątku całkowitego kapitałem własnym.

- HP.2. W publicznych przemysłowych spółkach akcyjnych notuje się występowanie silnej, pozytywnej relacji między efektywnością aktywów obrotowych a wskaźnikiem wspierania finansowego przedsiębiorstwa.

Badania empiryczne, zmierzające do realizacji postawionego celu badawczego oraz weryfikacji przyjętych hipotez, zrealizowane zostały wśród spółek publicznych należących do sektora przemysłu, które były notowane na rynku głównym Giełdy Papierów Wartościowych w Warszawie w latach 2006-2014 oraz których akcje były przedmiotem obrotu przez co najmniej pięć lat. Dodatkowym kryterium wyboru przedsiębiorstw do badań była dostępność rocznych jednostkowych sprawozdań finansowych w serwisie Notoria Serwis SA.

\section{Mierniki oceny efektywności ekonomicznej gospodarowania aktywami obrotowymi}

Rozpoczęcie działalności gospodarczej, jej dalsze prowadzenie i rozwój jest zawsze uwarunkowane uzyskiwaną efektywnością ekonomiczną gospodarowania aktywami obrotowymi. Efektywność tę można mierzyć zarówno z zastosowaniem ujęcia me- 
moriałowego, tj. przy użyciu danych zawartych w bilansie i rachunku zysków i strat, jak i z wykorzystaniem ujęcia kasowego, z uwzględnieniem danych liczbowych zawartych w rachunku przepływów pieniężnych.

W opracowaniu przyjęto, że ekonomiczna efektywność aktywów obrotowych będzie oceniana z uwzględnieniem miar, które obrazują fundamentalne podstawy tej efektywności, tkwiące w sprawnych i efektywnych procesach produkcji i sprzedaży określonych produktów i usług. Zaliczono do nich:

- wskaźnik przychodowości aktywów obrotowych (Wrca), będący miarą określającą wartość przychodów ze sprzedaży netto przypadającą na jedną złotówkę ulokowaną w tych aktywach. Jego postać jest następująca:

$$
\text { Wrca }=\frac{R_{t}}{C A_{t}},
$$

gdzie: Wrca - wskaźnik przychodowości aktywów obrotowych,

$R_{t} \quad-$ wartość przychodów ze sprzedaży w okresie $t$,

$C A_{t}$ - wartość aktywów obrotowych w okresie $t$;

- wskaźnik kosztochłonności majątku obrotowego ( $W k c a)$, będący miarą określającą poziom kosztów własnych przedsiębiorstwa (z podstawowej działalności operacyjnej) generowany jest przez jedną złotówkę zaangażowaną w aktywa obrotowe. Postać wskaźnika kosztochłonności aktywów obrotowych wygląda następująco:

$$
W k c a=\frac{K_{t}}{C A_{t}},
$$

gdzie: $W k c a$ - wskaźnik kosztochłonności aktywów obrotowych,

$K_{t} \quad-$ koszty uzyskania przychodów w okresie $t$,

pozostałe oznaczenia jak wyżej;

- wskaźnik rentowności aktywów obrotowych (RoSCA), będący miarą ukazującą generowany wynik ze sprzedaży przypadający na jedną złotówkę zaangażowaną w aktywa obrotowe przedsiębiorstwa. Wskaźnik ten stanowi kompleksową miarę oceny procesu gospodarowania aktywami obrotowymi, odnosi się on bowiem nie tylko do samego wyniku ze sprzedaży, lecz również do czynników go kształtujących, tj.: wartości przychodów ze sprzedaży i wartości kosztów ich uzyskania [Gabrusewicz 2011]. Formuła wskaźnika rentowności aktywów obrotowych przybiera następującą postać:

$$
\operatorname{RoSCA}=\frac{Z S_{t}}{C A_{t}},
$$

gdzie: RoSCA - wskaźnik rentowności aktywów obrotowych, 
$Z S_{t} \quad$ - zysk ze sprzedaży w okresie $t$, pozostałe oznaczenia jak wyżej;

- wskaźnik wydajności gotówkowej aktywów obrotowych (RoCFCA), określający zdolność aktywów obrotowych do pomnażania środków pieniężnych z podstawowej działalności przedsiębiorstwa. Zauważyć należy, że miara ta przybiera postać klasycznego wskaźnika płynności bieżącej przedsiębiorstwa. Opisywana miara przybiera następującą postać:

$$
\operatorname{RoCFCA}=\frac{O C F_{t}}{C A_{t}}
$$

gdzie: RoCFCA - wskaźnik wydajności gotówkowej aktywów obrotowych, $O C F_{t} \quad-$ operacyjne przepływy pieniężne w okresie $t$, pozostałe oznaczenia jak wyżej.

Jednocześnie za ważne kryterium i miernik oceny ekonomicznej efektywności aktywów obrotowych przedsiębiorstwa uznany został cykl obrotowy i odzwierciedlenie w nim długości czasu zamrożenia środków pieniężnych w działalność operacyjną przedsiębiorstwa. Można przyjąć, że od szybkości obiegu środków pieniężnych w przedsiębiorstwie zależą krótko- i długoterminowe efekty działalności każdej jednostki gospodarczej. Są to rezultaty o istotnym znaczeniu dla przedsiębiorstwa i jego wierzycieli, gdyż z jednej strony wskazują na zdolność przedsiębiorstwa do generowania m.in.: przychodów ze sprzedaży, rentowności operacyjnej i płynności finansowej, a z drugiej strony są ważną determinantą struktury finansowania przedsiębiorstwa, a tym samym być może i struktury kapitału. Długość cyklu obrotowego przedsiębiorstwa może być obliczana na dwa sposoby, przy czym:

- wskaźnik cyklu obrotowego brutto (cyklu operacyjnego - $O C_{t}$ ) określa liczbę dni, jakie upływają od momentu poniesienia wydatków na działalność operacyjną (np. zakup materiałów i surowców w przedsiębiorstwie produkcyjnym) do momentu uzyskania wpływów ze sprzedaży produktów lub usług. Jego formuła jest następująca:

$$
O C_{t}=\operatorname{In} T_{t}+D T_{t}
$$

gdzie: $O C_{t}-$ cykl obrotowy brutto w okresie $t$,

$\operatorname{In} T_{t}-$ cykl obrotu zapasami w okresie $t$,

$D T_{t}-$ cykl spływu należności krótkoterminowych w okresie $t$;

- wskaźnik cyklu obrotowego netto (konwersji gotówki-CC) jest skorygowaną wielkością cyklu obrotowego brutto o okres odroczenia płatności zobowiązań krótkoterminowych powstałych z tytułu dostaw i usług. Cykl obrotowy netto wskazuje tym samym na szybkość obiegu środków pieniężnych w przedsiębiorstwie i przyjmuje następującą postać: 


$$
C C_{t}=\operatorname{In} T_{t}+D T_{t}-C T_{t}
$$

gdzie: $C C_{t}-$ cykl obrotowy netto w okresie $t$,

$C T_{t}-$ cykl spłaty zobowiązań krótkoterminowych w okresie $t$, pozostałe oznaczenia jak wyżej.

\section{Dynamiczno-przestrzenna ocena zmian struktury finansowej i kapitałowej przemysłowych spółek giełdowych}

Racjonalizacja selekcji, doboru i późniejszego wykorzystania poszczególnych źródeł finansowania działalności podmiotu gospodarczego przejawiać się powinna w kształtowaniu takiej struktury finansowania oraz struktury kapitałowej, aby efekty płynące $\mathrm{z}$ ich zastosowania gwarantowały osiągnięcie satysfakcjonujących stóp zwrotu z zaangażowanego kapitału, z jednoczesną troską o zachowanie bezpiecznego poziomu płynności podmiotu gospodarczego w drodze harmonizacji strumieni przychodowych i wydatkowych w przedsiębiorstwie. Wiąże się ona zatem z potrzebą równoległego szacowania kosztów zaangażowanych źródeł finansowania oraz poziomu ryzyka z tym związanego, jak również możliwości podnoszenia rentowności funkcjonowania jednostki gospodarczej [Skowronek-Mielczarek 2003] ${ }^{1}$.

Dla scharakteryzowania strategii finansowania giełdowych spółek akcyjnych prowadzących działalność wytwórczą wykorzystane zostały mierniki obrazujące zarówno strukturę finansowania, jak i strukturę kapitału tychże jednostek ${ }^{2}$. Należały do nich:

\footnotetext{
${ }^{1}$ Wspomnieć należy, iż w literaturze przedmiotu problematyka optymalizacji struktury kapitału jest szeroko podejmowana (na niwie badań zarówno polskich, jak i zagranicznych) w odniesieniu do zagadnień teorii struktury kapitałowej przedsiębiorstwa. W najczęściej przytaczanych klasyfikacjach teorii struktury kapitału, dokonywanych ze względu na kryterium stanu, w którym dokonywana jest analiza, wyróżnia się teorie:

- statyczne, które konstruowane są zgodnie z założeniem, iż z góry określona jest wielkość kapitału niezbędnego do finansowania działalności gospodarczej, podstawowa zaś kwestia problematyczna tyczy się optymalizacji tej struktury. Nie dostrzega się nadto faktu, że przedsiębiorstwa dostosowują poziom zadłużenia w odpowiedzi na zmianę swojej wartości [Modigliani, Miller 1958; Fama, French 2005; Frank, Goyal 2009];

- dynamiczne, które zakładają, że ilość kapitału finansującego przedsiębiorstwo jest zmienna, podstawowym zaś zagadnieniem pozostaje kolejność, w jakiej należy pozyskiwać poszczególne źródła finansowania z perspektywy ich właścicieli [Donaldson 1961; Myers, Majluf 1984; Gajdka 2002; Barowicz 2014]. Kompleksowy podział teorii struktur kapitału zaprezentowali M. Harris i A. Raviv. Autorzy ci kategoryzacji teorii struktury kapitału dokonali ze względu na kryteria: kosztowe, podatkowe, kryterium dążenia podmiotu gospodarczego do osiągnięcia docelowego poziomu dźwigni finansowej itd. [Harris, Raviv 1991].

2 Struktura finansowania dotyczy w sposób bezpośredni struktury pasywów przedsiębiorstwa, czyli proporcji między wartością wszystkich kapitałów obcych a wartością kapitałów własnych wykorzystywanych w finansowaniu działalności operacyjnej i inwestycyjnej podmiotu gospodarczego [Szczepankowski 2007]. Z kolei struktura kapitałowa odnosi się do kształtowania układu kapitałów
} 
- wskaźnik sfinansowania majątku całkowitego kapitałem własnym - ETA (Equity to Total Assets Ratio), który przyjął następującą postać:

$$
E T A=\frac{E_{t}}{T A_{t}}
$$

gdzie: ETA - wskaźnik sfinansowania majątku całkowitego kapitałem własnym,

$E_{t}$ - księgowa wartość kapitału własnego w okresie $t$,

$T A_{t}$ - wartość aktywów ogółem w okresie $t$.

Wartość wskaźnika sfinansowania majątku całkowitego kapitałem własnym poniżej jedności $(E T A<1)$ informuje, że przedsiębiorstwo wykorzystuje zobowiązania i rezerwy na zobowiązania w finansowaniu swojej działalności. Tego rodzaju sytuacja wskazuje na potencjalne zagrożenie interesów właścicieli, wynikające z wzrostu ryzyka realizacji określonej stopy zwrotu z kapitału własnego. Jednocześnie im wyższa jest wartość omawianej miary, tym przedsiębiorstwo cechuje wyższy poziom bezpieczeństwa finansowego oraz mniejsza skłonność do ryzyka alokacji nadwyżek finansowych w rozwój inwestycyjny. Poziom kapitału własnego stanowi bowiem o wiarygodności danego przedsiębiorstwa i odzwierciedla gwarancje dla ewentualnych roszczeń jego wierzycieli. Jednocześnie oprócz zapewnienia wierzycielom możliwości otrzymania należnych im kwot, kapitały własne jako źródło finansowania o najdłuższym okresie wymagalności dają spółce możliwość kontynuowania działalności [Barburski 2014];

- wskaźnik wspierania finansowego DE - (Debt to Equity Ratio), określony następującym wzorem:

$$
D E=\frac{D_{t}}{E_{t}}
$$

gdzie: $D E$ - wskaźnik wspierania finansowego,

$D_{t}$ - wartość zobowiązań długoterminowych wraz z rezerwami finansowymi przeznaczonymi na sfinansowanie aktywów obrotowych netto w okresie $t$,

pozostałe oznaczenia jak wyżej.

W literaturze przedmiotu wskaźnik wspierania finansowego $D E$ jest często utożsamiany z długoterminową dźwignią finansową. Wskazuje ona na poziom zadłużenia długoterminowego przedsiębiorstwa i tym samym na jego wypłacalność.

stałych przedsiębiorstwa, tj.: kapitału własnego oraz zobowiązań długoterminowych i rezerw na te zobowiązania. Należy jednak pamiętać, że choć na gruncie teoretycznym nie ma problemu wyodrębniania tak rozumianej struktury kapitału ze struktury finansowej, sytuacja komplikuje się, jeśli istnieje potrzeba odniesienia teorii do rzeczywistych warunków gospodarowania. Nie wszystkie przedsiębiorstwa wykorzystują bowiem zobowiązania długoterminowe do finansowania swej działalności [Pasińska 2006]. 
Ponieważ poziom zadłużenia jednostki gospodarczej uznać można za odwrotnie proporcjonalny do poziomu jej wypłacalności, kryterium to jest ściśle powiązane z oceną zarówno bieżącej, jak i perspektywicznej zdolności kredytowej jednostki. Relacja wartości zobowiązań i rezerw na zobowiązania długoterminowe do wartości kapitału własnego uznana może być również za kryterium oceny bezpieczeństwa finansowania przedsiębiorstwa.

$\mathrm{Z}$ analizy przeprowadzonych badań empirycznych wynika, że w horyzoncie 2006-2014 średni udział kapitału własnego w pasywach ogółem publicznych przemysłowych spółek akcyjnych kształtował się na poziomie $E T A=0,61$ (zob. rys. 1). Jednocześnie na podstawie analizy średnich 9-letnich wartości wskaźników sfinansowania majątku całkowitego kapitałem własnym można stwierdzić, że w przemysłach: chemicznym, elektromaszynowym, farmaceutycznym, lekkim, paliwowym oraz tworzyw sztucznych zrealizowane zostały ponadprzeciętne średnie 9-letnie wartości tych wskaźników. Zwrócić należy uwagę na fakt, że najwyższa średnia wartość opisywanej miary została wygenerowana przez podmioty gospodarcze zaszeregowane do grona przedsiębiorstw przemysłu lekkiego $(E T A=0,69)$, z kolei najniższa charakterystyczna była dla spółek przynależących do sektora przemysłu drzewnego $(E T A=0,51)$.

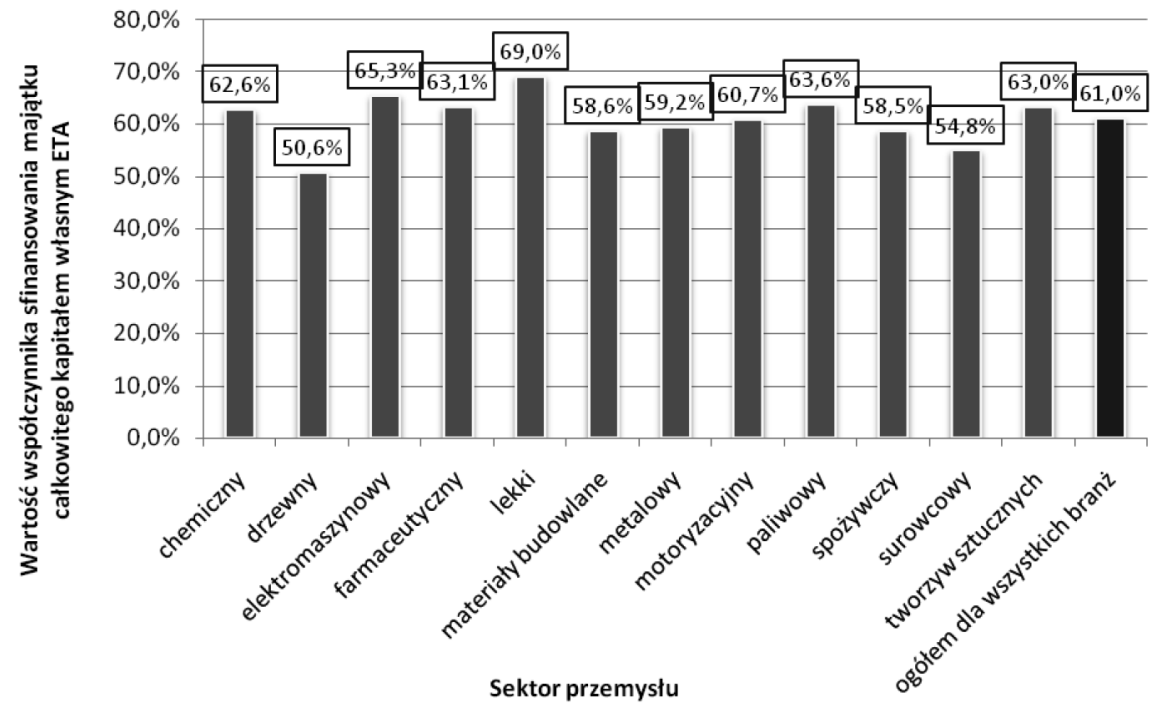

Rys. 1. Średnie 9-letnie branżowe wartości wskaźników sfinansowania majątku całkowitego kapitałem własnym ETA, obliczone dla giełdowych spółek przemysłowych w latach 2006-2014

Źródło: opracowanie własne na podstawie sprawozdań finansowych giełdowych spółek akcyjnych zamieszczonych w Notoria Serwis SA.

Obliczone środkowe 9-letnie wartości wskaźnika sfinansowania majątku całkowitego kapitałem własnym dla spółek giełdowych prowadzących działalność 
wytwórczą wskazują przy tym na podobny rozkład wartości analizowanej zmiennej w badanych branżach przemysłu (zob. rys. 2). Największe różnice w zakresie kształtowania średnich i środkowych 9-letnich wartości omawianej miary zanotowano w przedsiębiorstwach przemysłu surowcowego (średnia wartość wskaźnika ETA była mniejsza od jego wartości środkowej o 12,4 punktu procentowego). W generalnym ujęciu aż w dziesięciu sektorach przemysłu zaobserwowano występowanie lewostronnie asymetrycznego rozkładu badanej zmiennej. Jedynie w przypadku spółek zaszeregowanych do grona przemysłów paliwowego i spożywczego rozkład ten miał charakter prawostronnie asymetrycznego.

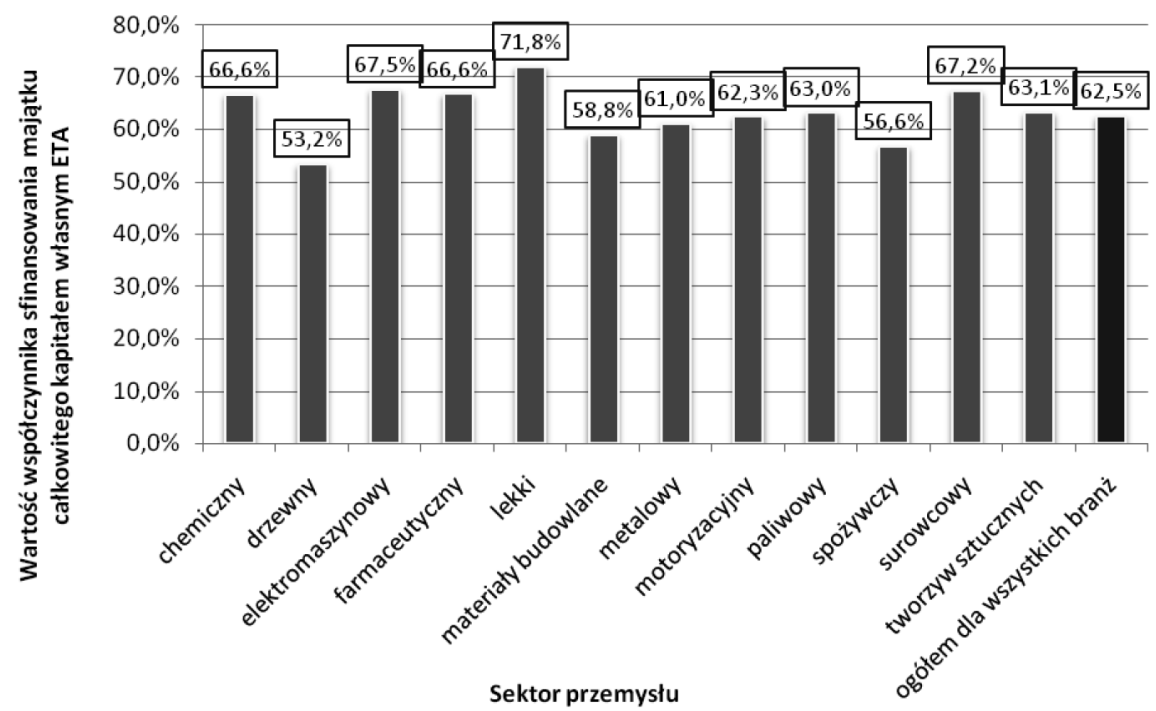

Rys. 2. Środkowe 9-letnie branżowe wartości wskaźników sfinansowania majątku całkowitego kapitałem własnym ETA, obliczone dla giełdowych spółek przemysłowych w latach 2006-2014

Źródło: opracowanie własne na podstawie sprawozdań finansowych giełdowych spółek akcyjnych zamieszczonych w Notoria Serwis SA.

Zdecydowanie większe dysproporcje zaobserwowano z punktu widzenia kształtowania się wśród badanej populacji średnich wartości wskaźnika wspierania finansowego $D E$ (zob. rys. 3). Z perspektywy ogółu giełdowych spółek akcyjnych prowadzących działalność wytwórczą w latach 2006-2014 średni stosunek zadłużenia długoterminowego w stosunku do wartości kapitału własnego oscylował wokół 20\%. Ponadprzeciętne średnie 9-letnie wartości wskaźników wspierania finansowego $D E$ były charakterystyczne dla spółek przynależących do następujących sektorów przemysłu: chemicznego, drzewnego, farmaceutycznego, materiałów budowlanych, paliwowego, spożywczego oraz tworzyw sztucznych. Najwyższą relacją zadłużenia długoterminowego w stosunku do księgowej wartości kapitału własnego cechowały 
ły się przy tym spółki prowadzące działalność wytwórczą w sektorach: drzewnym $(D E=0,33)$ oraz paliwowym $(D E=0,31)$. Natomiast najniższe średnie 9-letnie wartości wskaźnika wspierania finansowego $D E$ zaobserwowano wśród przedsiębiorstw należących do takich sektorów przemysłu, jak: elektromaszynowy $(D E=0,10)$, lekki $(D E=0,09)$ i motoryzacyjny $(D E=0,09)$.

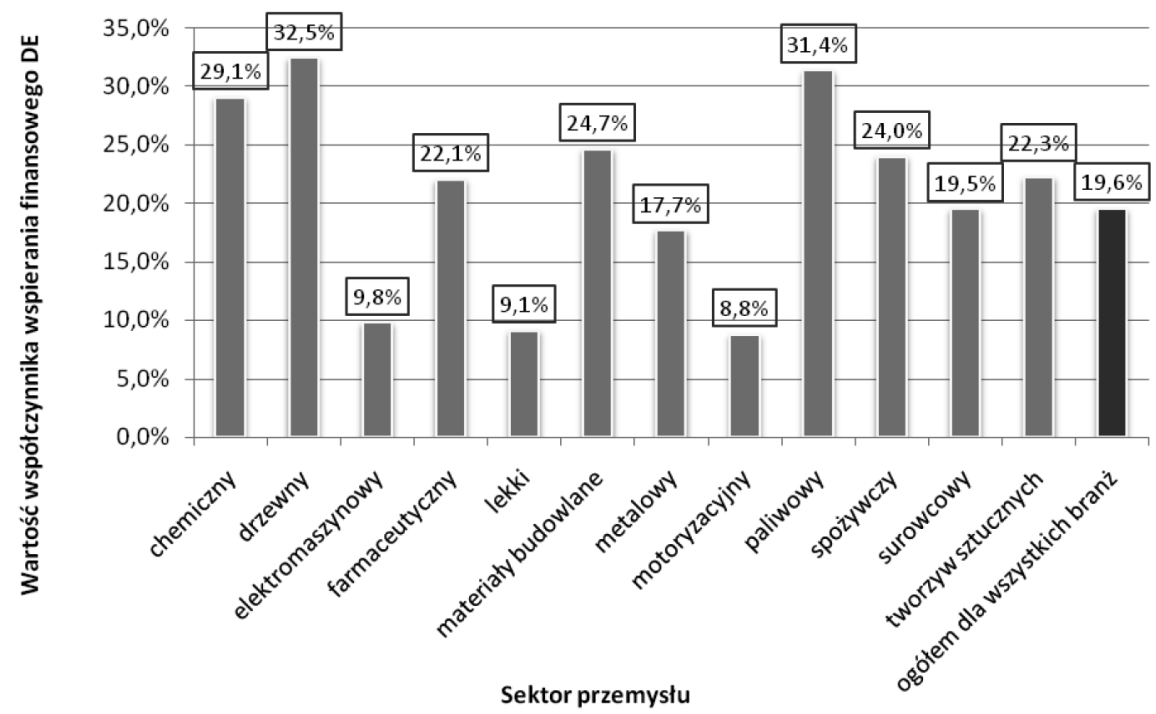

Rys. 3. Średnie 9-letnie branżowe wartości wskaźników wspierania finansowego $D E$, obliczone dla giełdowych spółek przemysłowych w latach 2006-2014

Źródło: opracowanie własne na podstawie sprawozdan finansowych giełdowych spółek akcyjnych zamieszczonych w Notoria Serwis SA.

Obliczone zaś środkowe 9-letnie wartości wskaźnika wspierania finansowego DE dla giełdowych spółek przemysłowych wskazują na odmienny rozkład wartości analizowanej zmiennej w badanych sektorach przemysłu (zob. rys. 4). Cechą charakterystyczną jest przy tym, że we wszystkich dwunastu branżach zaobserwowano występowanie prawostronnej asymetrii rozkładu badanej zmiennej. Oznacza to, że średnia 9-letnia wartość wskaźnika wspierania finansowego $D E$ była każdorazowo większa od mediany 9-letniej wartości tejże miary.

Wykazane międzybranżowe różnice w kształtowaniu wartości wskaźników: sfinansowania majątku całkowitego kapitałem własnym ETA oraz wspierania finansowego $D E$ przemysłowych spółek notowanych na GPW w Warszawie nie informują o powodach ich zaistnienia. Wydaje się jednak, że wskazane różnice wynikają nie tylko z charakteru branży, w której przedsiębiorstwo prowadzi działalność gospodarczą (tj.: ze specyfiki działań produkcyjnych, warunków produkcji, charakteru rynku zaopatrzenia i zbytu, wyposażenia technicznego itp.), ale także z indywidualnych 


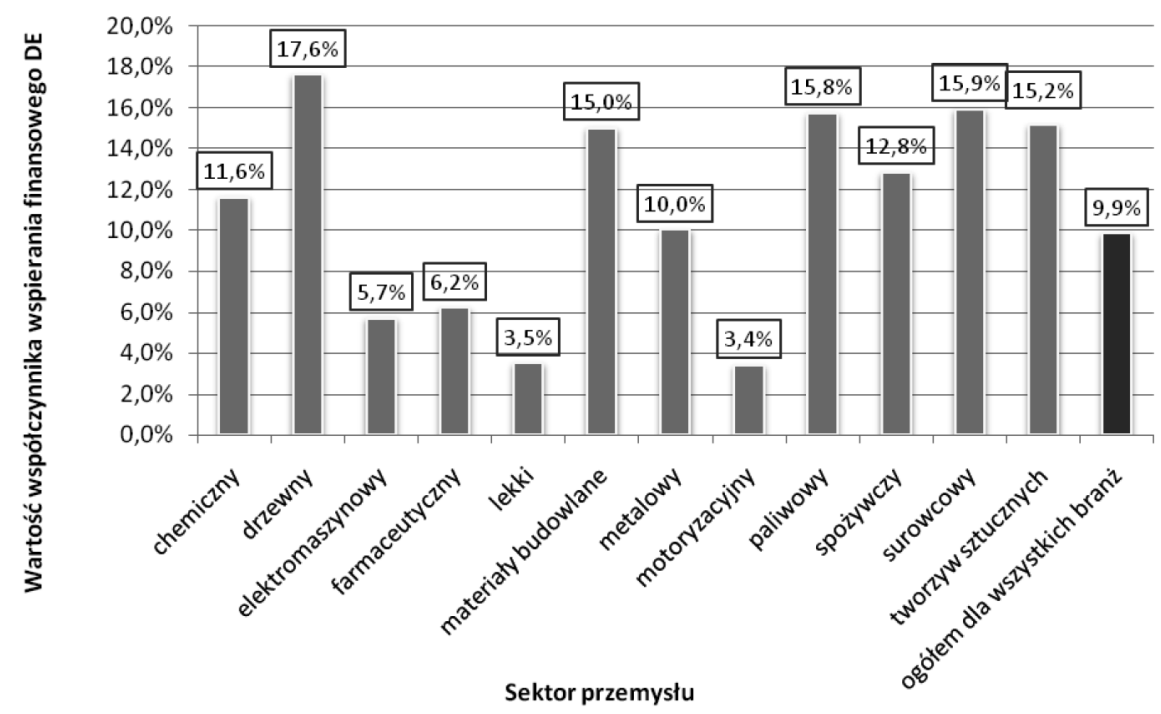

Rys. 4. Środkowe 9-letnie branżowe wartości wskaźników wspierania finansowego $D E$, obliczone dla giełdowych spółek przemysłowych w latach 2006-2014

Źródło: opracowanie własne na podstawie sprawozdan finansowych giełdowych spółek akcyjnych zamieszczonych w Notoria Serwis SA.

preferencji kadry zarządzającej odnośnie do: kształtowania odsetkowych korzyści podatkowych, przeciwdziałania przeinwestowaniu, utrzymania kontroli nad przedsiębiorstwem przez jego obecnych właścicieli, minimalizacji ryzyka bankructwa, zachowania zdolności do zaciągania zobowiązań w przyszłości (wysoki rating kredytowy), utrzymania zdolności do wypłat stabilnych dywidend itd.

\section{Memoriałowe i kasowe relacje struktury finansowania z efektywnością ekonomiczną aktywów obrotowych przemysłowych spółek giełdowych}

Pogłębione badania empiryczne nakierowane zostały na analizę relacji zachodzących między dwoma wcześniej przedstawionymi wskaźnikami określającymi strukturę finansową i kapitałową przedsiębiorstw przemysłowych notowanych na GPW w Warszawie (tj. wskaźnika sfinansowania majątku całkowitego kapitałem własnym ETA oraz wskaźnika wspierania finansowego $D E$ ) a czterema miernikami oceny fundamentalnych podstaw efektywności gospodarowania aktywami obrotowymi (tj. wskaźnikami: przychodowości aktywów obrotowych Wrca, kosztochłonności aktywów obrotowych $W k c a$, rentowności aktywów obrotowych RoSCA oraz wydajności gotówkowej aktywów obrotowych $R o C F C A$ ). 
Rezultaty analizy korelacji przeprowadzonej w odniesieniu do ogółu przemysłowych spółek giełdowych wskazują, że jedynie zależności między: przychodowością aktywów obrotowych ( $W r c a)$ a wskaźnikiem udziału kapitału własnego w finansowaniu majątku ogółem (ETA), jak również kosztochłonnością aktywów obrotowych $(W k c a)$ a wskaźnikiem sfinansowania majątku całkowitego kapitałem własnym (ETA) były istotnymi statystycznie korelacjami o co najmniej przeciętnej sile (zob. tab. 1). Siła tych ujemnie skorelowanych związków, mierzona za pomocą średniego wskaźnika korelacji rang Spearmana, wyniosła odpowiednio 30,8\% i $34,1 \%$. Pozostałe istotne ze statystycznego punktu widzenia związki zachodziły między wskaźnikiem wspierania finansowego $D E$ a wskaźnikami: przychodowości (Wrca), kosztochłonności (Wkca) oraz rentowności (RoSCA) aktywów obrotowych. Przybrały one postać pozytywnych relacji o nikłej sile zależności.

Analiza zależności występujących między analizowanymi zmiennymi, przeprowadzona $\mathrm{w}$ poszczególnych branżach przemysłu, uwypukliła fakt występowania znacznych zróżnicowań charakteru i siły badanych związków (zob. tab. 1). W pierwszej kolejności podkreślić należy, iż w giełdowych spółkach przemysłowych częściej notowano istotne ze statystycznego punktu widzenia powiązanie wskaźników efektywności ekonomicznej gospodarowania aktywami obrotowymi ze stopą udziału kapitału własnego w finansowaniu aktywów ogółem (ETA) aniżeli ze wskaźnikiem wspierania finansowego $D E$. Po drugie zaś, z syntetycznego zestawienia rezultatów badawczych wynika, że związki korelacyjne zachodzące między miarami efektywności ekonomicznej aktywów obrotowych a wskaźnikiem ETA zazwyczaj przyjmowały charakter relacji ujemnych, podczas gdy zależności mające miejsce między wskaźnikami efektywności ekonomicznej aktywów obrotowych a wskaźnikiem wspierania finansowego $D E$ zwykle przybierały formę relacji dodatnich.

Tabela 1. Związki przychodowości, kosztochłonności, rentowności i wydajności gotówkowej aktywów obrotowych ze strukturą finansową i kapitałową przemysłowych spółek akcyjnych notowanych na GPW w Warszawie w latach 2006-2014

\begin{tabular}{|c|c|c|c|c|}
\hline \multirow[t]{2}{*}{ Branża przemysłu } & \multirow{2}{*}{$\begin{array}{c}\text { Miara efektywności } \\
\text { gospodarowania } \\
\text { aktywami obrotowymi }\end{array}$} & \multicolumn{2}{|c|}{$\begin{array}{c}\text { Miara struktury finansowej } \\
\text { i kapitałowej przedsiębiorstwa }\end{array}$} & \multirow{2}{*}{$\begin{array}{c}\text { Liczba } \\
\text { obserwacji }\end{array}$} \\
\hline & & ETA & $D E$ & \\
\hline 1 & 2 & 3 & 4 & 5 \\
\hline \multirow[t]{4}{*}{ Spółki przemysłowe ogółem } & Wrca & $-0,308 * *$ & $0,219 * *$ & \multirow{4}{*}{$N=1160$} \\
\hline & Wkca & $-0,341 * *$ & $0,205 * *$ & \\
\hline & RoSCA & 0,050 & $0,075^{*}$ & \\
\hline & RoCFCA & 0,047 & 0,058 & \\
\hline \multirow{4}{*}{$\begin{array}{l}\text { Spółki z przemysłu } \\
\text { chemicznego }\end{array}$} & Wrca & $-0,463 * *$ & $0,556 * *$ & \multirow{4}{*}{$N=67$} \\
\hline & Wkca & $-0,532$ & $0,488 * *$ & \\
\hline & RoSCA & 0,019 & 0,180 & \\
\hline & RoCFCA & 0,082 & 0,115 & \\
\hline \multirow[t]{3}{*}{ Spółki z przemysłu drzewnego } & Wrca & $-0,277 * *$ & 0,157 & \multirow{3}{*}{$N=70$} \\
\hline & Wkca & $-0,192$ & 0,79 & \\
\hline & RoSCA & 0,118 & 0,144 & \\
\hline
\end{tabular}




\begin{tabular}{|c|c|c|c|c|}
\hline & RoCFCA & $-0,146$ & 0,047 & \\
\hline \multirow{4}{*}{$\begin{array}{l}\text { Spółki z przemysłu } \\
\text { elektromaszynowego }\end{array}$} & Wrca & $-0,278 * *$ & $-0,040$ & \multirow{4}{*}{$N=211$} \\
\hline & Wkca & $-0,332 * *$ & $-0,011$ & \\
\hline & RoSCA & $0,231 * *$ & $-0,071$ & \\
\hline & RoCFCA & $-0,071$ & $-0,064$ & \\
\hline \multirow{4}{*}{$\begin{array}{l}\text { Spółki z przemysłu } \\
\text { farmaceutycznego }\end{array}$} & Wrca & $-0,172$ & $0,293 * *$ & \multirow{4}{*}{$N=70$} \\
\hline & Wkca & $-0,414 * *$ & $0,281 *$ & \\
\hline & RoSCA & $0,388 * *$ & 0,152 & \\
\hline & RoCFCA & 0,207 & $0,369 * *$ & \\
\hline \multirow[t]{4}{*}{ Spółki z przemysłu lekkiego } & Wrca & $-0,472 * *$ & $0,369 * *$ & \multirow{4}{*}{$N=81$} \\
\hline & Wkca & $-0,405 * *$ & $0,285^{*}$ & \\
\hline & RoSCA & $-0,046$ & 0,170 & \\
\hline & RoCFCA & $-0,176$ & 0,151 & \\
\hline \multirow{4}{*}{$\begin{array}{l}\text { Spółki z przemysłu } \\
\text { materiałów budowlanych }\end{array}$} & Wrca & $-0,261 * *$ & 0,056 & \multirow{4}{*}{$N=167$} \\
\hline & Wkca & $-0,253 * *$ & 0,036 & \\
\hline & RoSCA & $-0,240 * *$ & $0,199 * *$ & \\
\hline & RoCFCA & $-0,579 * *$ & 0,106 & \\
\hline \multirow{4}{*}{$\begin{array}{l}\text { Spółki z przemysłu } \\
\text { metalowego }\end{array}$} & Wrca & 0,127 & $-0,127$ & \multirow{4}{*}{$N=153$} \\
\hline & Wkca & 0,092 & $-0,094$ & \\
\hline & $\operatorname{RoSCA}$ & 0,105 & $-0,016$ & \\
\hline & RoCFCA & 0,069 & $-0,057$ & \\
\hline \multirow{4}{*}{$\begin{array}{l}\text { Spółki z przemysłu } \\
\text { motoryzacyjnego }\end{array}$} & Wrca & $-0,039$ & $-0,155$ & \multirow{4}{*}{$N=45$} \\
\hline & Wkca & $-0,226$ & 0,095 & \\
\hline & RoSCA & $0,395 * *$ & $-0,452 * *$ & \\
\hline & RoCFCA & $0,374 * *$ & $-0,491 * *$ & \\
\hline \multirow{4}{*}{$\begin{array}{l}\text { Spółki z przemysłu } \\
\text { paliwowego }\end{array}$} & Wrca & $-0,696 * *$ & $0,585 * *$ & \multirow{4}{*}{$N=45$} \\
\hline & Wkca & $-0,735 * *$ & $0,603 * *$ & \\
\hline & RoSCA & $-0,254$ & 0,185 & \\
\hline & RoCFCA & $-0,223$ & 0,200 & \\
\hline \multirow{4}{*}{$\begin{array}{l}\text { Spółki z przemysłu } \\
\text { spożywczego }\end{array}$} & Wrca & $-0,522 * *$ & $0,340 * *$ & \multirow{4}{*}{$N=168$} \\
\hline & Wkca & $-0,573 * *$ & $0,343 * *$ & \\
\hline & RoSCA & $-0,199 * *$ & 0,161* & \\
\hline & RoCFCA & $-\mathbf{0 , 1 5 8 *}$ & 0,024 & \\
\hline \multirow{4}{*}{$\begin{array}{l}\text { Spółki z przemysłu } \\
\text { surowcowego }\end{array}$} & Wrca & $-0,064$ & 0,269 & \multirow{4}{*}{$N=30$} \\
\hline & Wkca & $-0,298$ & $0,363^{*}$ & \\
\hline & $\operatorname{RoSCA}$ & $0,534 * *$ & 0,128 & \\
\hline & RoCFCA & $0,356 *$ & $0,406 * *$ & \\
\hline \multirow{4}{*}{$\begin{array}{l}\text { Spółki z przemysłu tworzyw } \\
\text { sztucznych }\end{array}$} & Wrca & $-0,578 * *$ & $0,291 *$ & \multirow{4}{*}{$N=53$} \\
\hline & Wkca & $-0,539 * *$ & 0,245 & \\
\hline & RoSCA & $-0,039$ & 0,133 & \\
\hline & RoCFCA & $-0,044$ & 0,126 & \\
\hline
\end{tabular}

Czcionką pogrubioną oznaczono korelacje istotne pod względem statystycznym, przy czym:

* korelacje statystycznie istotne przy przyjętym poziomie istotności $\alpha=0,05 ; * *$ korelacje statystycznie istotne przy przyjętym poziomie istotności $\alpha=0,01$.

Źródło: opracowanie własne na podstawie sprawozdań finansowych giełdowych spółek akcyjnych zamieszczonych w Notoria Serwis SA. 


\section{Relacje struktury finansowania $\mathrm{z}$ cyklem obrotowym przemysłowych spółek giełdowych}

Badanie związków zachodzących między strukturą finansowania a cyklem obrotowym przemysłowych spółek akcyjnych zorientowane jest na udzielenie odpowiedzi na pytanie: czy najbardziej płynne składniki aktywów obrotowych przedsiębiorstwa w silniejszym stopniu związane są ze strukturą kapitałową przedsiębiorstwa czy też ze strukturą finansową?

Tabela 2. Związki cyklu obrotowego przedsiębiorstwa ze strukturą finansową i kapitałową przemysłowych spółek akcyjnych notowanych na GPW w Warszawie w latach 2006-2014

\begin{tabular}{|c|c|c|c|c|}
\hline \multirow[t]{2}{*}{ Branża przemysłu } & \multirow{2}{*}{$\begin{array}{c}\text { Miara efektywności } \\
\text { gospodarowania } \\
\text { aktywami obrotowymi }\end{array}$} & \multicolumn{2}{|c|}{$\begin{array}{l}\text { Miara struktury finansowej } \\
\text { i kapitałowej przedsiębiorstwa }\end{array}$} & \multirow{2}{*}{$\begin{array}{c}\text { Liczba } \\
\text { obserwacji }\end{array}$} \\
\hline & & ETA & $D E$ & \\
\hline 1 & 2 & 3 & 4 & 5 \\
\hline \multirow[t]{2}{*}{ Spółki przemysłowe ogółem } & $C C$ & $0,441 * *$ & $-0,210 * *$ & \multirow{2}{*}{$N=1160$} \\
\hline & $O C$ & $0,083 *$ & $-0,005$ & \\
\hline \multirow{2}{*}{$\begin{array}{l}\text { Spółki z przemysłu } \\
\text { chemicznego }\end{array}$} & $C C$ & $0,601 * *$ & $-0,403 * *$ & \multirow{2}{*}{$N=67$} \\
\hline & $O C$ & $0,473 * *$ & $-0,298$ & \\
\hline \multirow[t]{2}{*}{ Spółki z przemysłu drzewnego } & $C C$ & $0,563 * *$ & $-0,224$ & \multirow{2}{*}{$N=70$} \\
\hline & $O C$ & $-0,213$ & $0,371 * *$ & \\
\hline \multirow{2}{*}{$\begin{array}{l}\text { Spółki z przemysłu } \\
\text { elektromaszynowego }\end{array}$} & $C C$ & $0,630 * *$ & $-0,204 * *$ & \multirow{2}{*}{$N=211$} \\
\hline & $O C$ & 0,153 & $0,210 * *$ & \\
\hline \multirow{2}{*}{$\begin{array}{l}\text { Spółki z przemysłu } \\
\text { farmaceutycznego }\end{array}$} & $C C$ & $0,490 * *$ & $-0,405 *$ & \multirow{2}{*}{$N=70$} \\
\hline & $O C$ & $-0,127$ & 0,065 & \\
\hline \multirow[t]{2}{*}{ Spółki z przemysłu lekkiego } & $C C$ & $-0,038$ & $-0,42$ & \multirow{2}{*}{$N=81$} \\
\hline & $O C$ & 0,119 & $-0,106$ & \\
\hline \multirow{2}{*}{$\begin{array}{l}\text { Spółki z przemysłu } \\
\text { materiałów budowlanych }\end{array}$} & $C C$ & $0,452 * *$ & 0,015 & \multirow{2}{*}{$N=167$} \\
\hline & $O C$ & 0,107 & 0,146 & \\
\hline \multirow{2}{*}{$\begin{array}{l}\text { Spółki z przemysłu } \\
\text { metalowego }\end{array}$} & $C C$ & $0,531 * *$ & $-0,344 * *$ & \multirow{2}{*}{$N=153$} \\
\hline & $O C$ & $-0,227 * *$ & $0,246 * *$ & \\
\hline \multirow{2}{*}{$\begin{array}{l}\text { Spółki z przemysłu } \\
\text { motoryzacyjnego }\end{array}$} & $C C$ & 0,067 & 0,008 & \multirow{2}{*}{$N=45$} \\
\hline & $O C$ & $-0,254$ & 0,256 & \\
\hline \multirow{2}{*}{$\begin{array}{l}\text { Spółki z przemysłu } \\
\text { paliwowego }\end{array}$} & $C C$ & $-0,128$ & 0,176 & \multirow{2}{*}{$N=45$} \\
\hline & $O C$ & 0,151 & $-0,103$ & \\
\hline \multirow{2}{*}{$\begin{array}{l}\text { Spółki z przemysłu } \\
\text { spożywczego }\end{array}$} & $C C$ & $0,315 * *$ & $-0,119$ & \multirow{2}{*}{$N=168$} \\
\hline & $O C$ & 0,114 & 0,029 & \\
\hline \multirow{2}{*}{$\begin{array}{l}\text { Spółki z przemysłu } \\
\text { surowcowego }\end{array}$} & $C C$ & $0,616 * *$ & $-0,065$ & \multirow{2}{*}{$N=30$} \\
\hline & $O C$ & $-0,044$ & $-0,417 * *$ & \\
\hline \multirow{2}{*}{$\begin{array}{l}\text { Spółki z przemysłu tworzyw } \\
\text { sztucznych }\end{array}$} & $C C$ & $0,797 * *$ & $-0,442 * *$ & \multirow{2}{*}{$N=53$} \\
\hline & $O C$ & $0,601 * *$ & $-0,315$ & \\
\hline
\end{tabular}

Czcionką pogrubioną oznaczono korelacje istotne pod względem statystycznym, przy czym:

* korelacje statystycznie istotne przy przyjętym poziomie istotności $\alpha=0,05 ; * *$ korelacje statystycznie istotne przy przyjętym poziomie istotności $\alpha=0,01$.

Źródło: opracowanie własne na podstawie sprawozdań finansowych giełdowych spółek akcyjnych zamieszczonych w Notoria Serwis SA. 
Wyniki analizy korelacji przeprowadzonej dla ogółu przemysłowych spółek giełdowych wskazują, że do grona związków o przeciętnej sile zaliczyć można relację między wskaźnikiem sfinansowania majątku całkowitego kapitałem własnym $(E T A)$ a wskaźnikiem cyklu obrotowego netto (CC) (zob. tab. 2). Siła tej dodatniej korelacji, mierzona wskaźnikiem korelacji rang Spearmana, wyniosła 44,1\%. Natomiast do istotnych statystycznie zależności o nikłej sile zakwalifikować należy związki zachodzące między wskaźnikiem ETA i cyklem obrotowym brutto $(O C)$ oraz między wskaźnikiem długoterminowej dźwigni finansowej $(D E)$ a cyklem konwersji gotówki (CC).

Rezultaty przeprowadzonych badań empirycznych nad zależnościami występującymi między analizowanymi zmiennymi w poszczególnych branżach przemysłu wskazują na występowanie znacznych zróżnicowań charakteru i siły badanych związków. Zauważyć przeto należy, że spośród wszystkich analizowanych relacji to związki korelacyjne zachodzące między stopą sfinansowania majątku ogółem kapitałem własnym (ETA) a wskaźnikiem cyklu obrotowego netto $(C C)$ przedsiębiorstw przemysłowych cechują się najwyższą siłą zależności (w spółkach przemysłu tworzyw sztucznych wynosi ona aż 79,7\%). Są to jednocześnie związki, które każdorazowo przybierają postać relacji o dodatnim charakterze. Z kolei statystycznie istotne związki pojawiające się w poszczególnych branżach przemysłu między wskaźnikiem wspierania finansowego $(D E)$ a cyklem konwersji gotówki $(C C)$ we wszystkich analizowanych przypadkach odznaczały się negatywnym charakterem korelacji i stosunkowo niewielką siłą zależności. Rezultaty przeprowadzonych badań empirycznych wskazują także na dość rzadkie ze statystycznego punktu widzenia powiązanie wskaźników struktury finansowej i kapitałowej przedsiębiorstw przemysłowych z kategorią cyklu operacyjnego $(O C)$ (zob. tab. 2).

\section{Zakończenie}

Aktywa obrotowe są tymi składnikami majątkowymi, które ,żyją” skalą i rytmem działania przedsiębiorstwa, będąc jednocześnie odzwierciedleniem efektów jego funkcji na rynku. W odzwierciedleniu tym zawierają się także warunki zewnętrznego i wewnętrznego otoczenia, w którym podmiot gospodarczy funkcjonuje, mające swój wyraz m.in. w występujących w przedsiębiorstwie relacjach własnościowo-kapitałowych.

Wyniki przeprowadzonych badań empirycznych pozwoliły na zanegowanie obu postawionych na wstępie hipotez badawczych. Wykazały one bowiem, iż wzrost udziału kapitału własnego w ogólnej strukturze pasywów przedsiębiorstwa jedynie w statystycznie przeciętny sposób przyczynia się do spadku wartości wskaźników: przychodowości oraz kosztochłonności aktywów obrotowych. Co więcej, stopa sfinansowania kapitałem własnym majątku całkowitego nie wpływała również w sposób istotny statystycznie na kształtowanie wartości wskaźnika wydajności gotówkowej aktywów obrotowych tych jednostek. Z kolei analiza powiązań efektywności 
ekonomicznej aktywów obrotowych ze strukturą kapitałową badanych podmiotów wykazała występowanie istotnych statystycznie, pozytywnych związków między wskaźnikiem wspierania finansowego a wskaźnikami: przychodowości, kosztochłonności i rentowności aktywów obrotowych. Były to jednak relacje o nikłej sile.

Analiza związków strategii finansowania z cyklem obrotowym przedsiębiorstw przemysłowych nie potwierdziła przypuszczenia, iż wzrost udziału kapitału własnego w finansowaniu pasywów ogółem przyczynia się do wzrostu ich płynności. Zauważono bowiem, że cykl konwersji gotówki wydłuża się wraz ze wzrostem wartości wskaźnika sfinansowania majątku całkowitego kapitałem własnym. Jednocześnie długość cyklu obrotowego netto malała wraz ze wzrostem długoterminowej dźwigni finansowej. Warto jednak podkreślić, iż siła i kierunek opisywanych zależności wyraźnie różnicował się ze względu na branżę przemysłu, w których poszczególne przedsiębiorstwa działają.

Rezultaty badań empirycznych, choć nie mogą być wystarczającą przesłanką wnioskowania o charakterze bardziej zgeneralizowanym, potwierdzają jednak poglądy, iż efektywność procesu gospodarowania aktywami obrotowymi jest zmiennym produktem interakcji z innymi procesami zachodzącymi w przedsiębiorstwie, stając się w ten sposób w łańcuchu zdarzeń zarazem przyczyną, jak i efektem działania podmiotu gospodarczego.

\section{Literatura}

Barburski J., 2014, Kapitały własne jako podstawa bezpieczeństwa działalności gospodarczej na przykładzie przedsiębiorstw WIG20, Zeszyty Naukowe Uniwersytetu Szczecińskiego nr 804. Finanse, Rynki Finansowe, Ubezpieczenia, nr 67 (2014), Wydawnictwo Uniwersytetu Szczecińskiego, Szczecin.

Barowicz M., 2014, Determinanty struktury kapitałowej przedsiębiorstwa. Podejście empiryczne, Wydawnictwo edu-Libri, Kraków.

Donaldson G., 1961, Corporate Debt Capacity: A Study of Corporate Debt Policy and the Determinants of Corporate Debt Capacity, "Division of Research", Harvard Graduate School of Business Administration, Boston.

Fama E.F., French K.R., 2005, Financing decisions: who issues stock?, Journal of Financial Economics, vol. 76, no. 3, s. 549-582.

Frank M.Z., Goyal V.K., 2009, Capital structure decisions: which factors are reliably important?, Financial Management, vol. 38, no. 1, s. 217-248.

Gabrusewicz W., 2011, Sprawozdanie finansowe przedsiębiorstw jednostkowe i skonsolidowane, PWE, Warszawa.

Gajdka J., 2002, Teorie struktury kapitału i ich aplikacja w warunkach polskich, Wydawnictwo Uniwersytetu Łódzkiego, Łódź.

Harris M., Raviv A., 1991, The theory of capital structure, Journal of Finance, vol. 46, no. 1, s. 297-355. Modigliani F., Miller M.H., 1958, The cost of capital, corporation finance and the theory of investment, American Economic Review, vol. 48, no. 3, s. 261-297.

Myers S.C., Majluf N.S., 1984, Corporate financing and investment decisions when firms have information that investors do not have, Journal of Financial Economics, vol. 13(2), s. 187-221. 
Nowak M., 2002, Wskaźniki oparte na przeptywach pieniężnych, Monitor Rachunkowości i Finansów, nr 6.

Pasińska D., 2006, Wpływ zabezpieczania dtugu majątkiem na strukturę kapitatu przedsiębiorstwa, Acta Universitatis Lodziensis. Folia Oeconomica, nr 200, Wydawnictwo Uniwersytetu Łódzkiego, Łódź.

Skowronek-Mielczarek A., 2003, Wybory źródet finansowania w matych i średnich przedsiębiorstwach, [w:] Orechwa-Maliszewska E., Kopczuk A. (red.), Finansowe aspekty funkcjonowania małych i średnich przedsiębiorstw, Wydawnictwo Wyższej Szkoły Finansów i Zarządzania w Białymstoku, Białystok.

Szczepankowski P., 2007, Wycena i zarządzanie wartościa przedsiębiorstwa, Wydawnictwo Naukowe PWN, Warszawa. 